\section{Studia}

\section{z Filologii Polskiej i Słowiańskiej}

DOI: $10.11649 /$ sfps.1780
Studia z Filologii Polskiej i Słowiańskiej, 54

Warszawa 2019

Article No. 1780

Citation:

Jaros, V. (2019). Charakterystyka języka familijnego Joachima Lelewela dotyczącego społecznej przestrzeni rodziny (na podstawie listów do najbliższych). Studia z Filologii Polskiej i Słowiańskiej, 54. https://doi.org/10.11649/sfps.1780

\author{
Violetta Jaros \\ (Uniwersytet Humanistyczno-Przyrodniczy \\ im. Jana Długosza w Częstochowie)
}

\title{
Charakterystyka języka familijnego Joachima Lelewela dotyczącego społecznej przestrzeni rodziny (na podstawie listów do najbliższych)
}

Idiolek $\mathrm{t}^{1}$ Joachima Lelewela - wybitnego historyka pierwszej połowy XIX wieku, nazywanego „ojcem” naukowej historiografii polskiej (Maternicki, 2009, s. 56) nie doczekał się jeszcze pełnego opracowania ${ }^{2}$. Niniejszy szkic stanowi przyczynek do poznania jego języka osobniczego, a ściślej - próbę wskazania właściwości

1 Idiolekt pojmowany jest tu jako „całość kompetencji językowej jednostki (a nie jedynie komponenty indywidualne, osobnicze)” (Kozłowska, 2011, s. 94). Osobisty repertuar systemu środków językowych jednostki kształtuje się w ciągu jej działalności życiowej poprzez przyswajanie różnych odmian języka (m.in. socjolektalnej, terytorialnej) i pozyskiwanie subkompetencji niezbędnych do udziału w poszczególnych typach komunikacji językowej (Gajda, 1988, s. 381). Stopień zróżnicowania idiolektu zależny jest także od odgrywanych przez jednostkę ról społecznych (Bokszański, Piotrowski, \& Ziółkowski, 1977, ss. 73-74).

${ }^{2}$ Dotychczasowe badania nad językiem Lelewela dotyczyły zagadnień związanych z neologizmami (m.in. Jaros, 2009, 2014; Lewaszkiewicz, 1976), charakterystyki właściwości systemowych (m.in. Jaros, 2013; Urbańczyk, 1983) oraz języka naukowego (Jaros, 2015).

This is an Open Access article distributed under the terms of the Creative Commons Attribution 3.0 PL License (creativecommons.org/licenses/by/3.0/pl/), which permits redistribution, commercial and non-commercial, provided that the article is properly cited. (c) The Author(s) 2019.

Publisher: Institute of Slavic Studies, Polish Academy of Sciences

[Wydawca: Instytut Slawistyki Polskiej Akademii Nauk] 
języka familijnego ${ }^{3}$ autora Polski wieków średnich. Charakterystyka ograniczona została do repertuaru zjawisk językowych dotyczących społecznej przestrzeni rodziny. Na podstawę materiałową składa się dwutomowy zbiór korespondencji (zob. Źródła; Lelewel, 1878, 1879) pisanej z wielu miejsc pobytu (Woli Okrzejskiej, Warszawy, Wilna, Krzemieńca, Łucka, Abbeville, Tours, Brukseli) w różnych okresach życia Lelewela, który wcześnie opuścił rodzinny dom, ale w wymienianych $\mathrm{z}$ rodzicami i rodzeństwem listach ${ }^{4}$ dawał wyraz swego przywiązania i tęsknoty, żywego zainteresowania losami najbliższych i znajomych, co ilustrują poniższe fragmenty $\mathrm{z}$ jego listów do brata Prota:

Najmniejsze słówko twoje jest mi najmilsze, ani mnie znudzić może, mało dziesięć razy odczytywałem z prawdziwem rozczuleniem, i dopóty odczytywać będę, póki mi nowych wyrazów do wzbudzania i drażnienia najszczerszego przywiązania nie nadeślesz. Bądź zdrów i tyle mnie kochaj i o mnie pamiętaj ile ja o tobie. Najprzywiązańszy brat J. Lelewel (I 161) ;

\section{i siostry, Marii Majewskiej:}

Pisujcież tak jak ja, a będę wiedział co się z Wami dzieje, czyś siostra podzdrowiała czy Jan [szwagier Lelewela - V. J.] zdrów, wesół, wyłysiał, czy nie?; stracił zęby, czy nie? Do Ewci [siostrzenica Lelewela - V. J.] wiele umizgów, czy który dośpiewa, rodzicom jej jak się wiedzie? co Huguś [chrześniak Lelewela, niepełnosprawny syn Marii - V. J.] porabia, co jego braciszkowie, co siostrzyczki? Co matka, co ojciec? Oh! jak wy skąpi w słowach. Niech Was Bóg błogosławi (II 419).

${ }^{3}$ Język familijny // rodzinny // domowy definiowany jest jako język służący komunikacji w kręgu rodzinno-przyjacielsko-sąsiedzkim, który łączą mocne i długotrwałe związki, zwłaszcza relacje pokrewieństwa i powinowactwa oraz więzy uczuciowe (Handke, 2008, s. 76). „W kręgu familijnym - jak pisze badaczka - kształtują się umiejętności i nawyki językowe w najważniejszym okresie życia każdego z członków wspólnoty: etnicznej, narodowej, regionalnej, lokalnej, środowiskowej" (Handke, 2008, s. 89).

${ }^{4}$ Właściwości strukturalne listu, zdaniem A. Kałkowskiej (Kałkowska, 1982, ss. 11-13), zdeterminowane są m.in. sytuacją fizyczną (jest ogniwem dialogu i językowym wykładnikiem stosunku na linii nadawca - odbiorca), sytuacją społeczną (jest wytworem indywidualnym realizowanym w języku nieoficjalnym, łącząc przy tym „właściwości podrzędnych odgałęzień języka nieoficjalnego: literackiego i potocznego”), tekstem pragmatycznym o podwójnym zamierzeniu: ekspresywno-impresywnym i informacyjnym. Prywatna korespondencja, odzwierciedlając kulturę i obyczajowość uczestników dialogu epistolarnego, odsłania specyfikę komunikacji wewnątrzrodzinnej, prezentując nawyki i zachowania językowe członków rodziny.

${ }^{5}$ Cytaty i materiał egzemplifikacyjny podawany jest za wymienionym zbiorem listów Lelewela do najbliższych (Lelewel, 1878, 1879). Cyfra rzymska oznacza numer tomu, cyfra arabska - numer strony. 
Joachim Lelewel ${ }^{6}$ urodził się w Warszawie 22 marca 1786 roku. Rodzina ze strony ojca wywodziła się z Prus Książęcych i pisała się Loelhoeffel de Löwensprung. Przybyły do Polski dziadek Joachima, Henryk, około 1730 roku został nadwornym lekarzem króla Augusta III. Babka zaś, Konstancja Jauch, wywodziła się z Saksonii. W 1775 roku ojciec uczonego, Karol, wieloletni członek Komisji Edukacji Narodowej, uzyskał indygenat polski i odtąd posługiwał się spolszczonym nazwiskiem Lelewel. Ożenił się z Ewą z Szeluttów, która ze strony ojca pochodziła $\mathrm{z}$ białoruskiej szlachty, a ze strony matki skoligacona była ze starymi rodzinami polskimi osiadłymi na Mazowszu i Wołyniu.

Joachim wychowywał się w patriotycznej i patriarchalnej atmosferze rodzinnego domu, w którym pielęgnowano tradycje staroświeckie. Był najstarszym z pięciorga rodzeństwa - trzech braci i dwóch sióstr. Rodzice po upadku Rzeczypospolitej przenieśli się do nabytego majątku w Woli Cygowskiej na Podlasiu. Pierwsze nauki pobierał u proboszcza w Okrzei. Lata młodzieńcze Lelewela wiążą się głównie z Warszawą, gdzie w 1801 roku oddany został do konwiktu pijarskiego, i Wilnem, gdzie w 1804 roku rozpoczął naukę w studium pedagogicznym Cesarskiego Uniwersytetu Wileńskiego jako stypendysta kandydat do stanu nauczycielskiego.

Po zakończeniu studiów w marcu 1809 r. udał się do Krzemieńca, by odpracować stypendium jako nauczyciel historii. W połowie 1811 roku wrócił do Warszawy, gdzie ojciec pomógł mu w objęciu posady w Ministerstwie Spraw Wewnętrznych. Jednak zajęcie biurowe nie satysfakcjonowało młodego „zdziełcy”, który myślał o karierze badawczej. Łączył ją z pracą pedagogiczną na Uniwersytecie Wileńskim, gdzie spędził łącznie dziewięć lat. Najpierw (1815-1818) jako zastępca profesora, potem (1821-1824) jako profesor historii powszechnej. W międzyczasie (1819-1821) objął stanowisko kustosza Biblioteki Głównej w Warszawie. Szczęśliwy okres pracy w Uniwersytecie Wileńskim został zakończony przez ukaz carski z 14 sierpnia 1824 roku.

Jesienią opuścił historyk Wilno i udał się do Warszawy. Nie podjął stałego zatrudnienia, rozpoczął natomiast intensywną działalność polityczną: został członkiem tajnych organizacji - Wolnomularstwa Narodowego oraz Towarzystwa Patriotycznego - oraz posłem Sejmu Królestwa Polskiego. Po wybuchu powstania listopadowego Lelewel wszedł w skład kierowanej przez Adama Czartoryskiego Rady Administracyjnej, a następnie Rządu Narodowego.

6 Biografia uczonego przedstawiona została dzięki wykorzystaniu informacji zawartych w monografiach S. Kieniewicza (Kieniewicz, 1990) oraz H. Więckowskiej (Więckowska, 1980). 
Drugą połowę życia, po upadku powstania, spędził we Francji (Paryż, La Grange, Tours) i Belgii (Bruksela). Na emigracji kontynuował działalność polityczną: w 1831 r. zawiązał Komitet Narodowy Polski, w 1835 r. wszedł w skład Komitetu Młodej Polski, w 1837 r. założył Zjednoczenie Emigracji Polskiej, a dziesięć lat później został wiceprezesem Międzynarodowego Towarzystwa Demokratycznego. Z czasem stopniowo zaczął odsuwać się od polityki. Przez cały okres pobytu na emigracji pracował naukowo i korespondował z rodzeństwem, przyjmował gości w swym skromnym mieszkanku na poddaszu Estaminet da Varsovie („Gospody Warszawskiej”). Zmarł 29 maja 1861 roku.

Regularna wymiana listów z najbliższymi pozwalała Lelewelowi uczestniczyć we wszystkich rodzinnych wydarzeniach, dowiadywać się na bieżąco o tym, co dzieje się w domu, a później, po usamodzielnieniu się rodzeństwa, w rodzinach braci i sióstr, dzielić się swoimi przeżyciami i troskami. Z korespondencji czerpał też informacje o losach dalszych krewnych, sąsiadów i znajomych, sam również donosił o różnych zdarzeniach czy spotkanych osobach, nie szczędząc szczegółowych relacji i opisów.

Charakterystyka języka familijnego Joachima Lelewela dotyczącego społecznej przestrzeni rodziny przedstawiona zostanie ze względu na trzy komponenty: wskazywanie na relacje rodzinne, formy bezpośredniego osobistego kontaktu w rodzinie oraz emocjonalność w komunikacji wewnątrzrodzinnej.

\section{Wskazywanie na relacje rodzinne}

\subsection{Nazwy członków rodziny}

Badana proza epistolarna, stanowiąca jednostkową realizację języka familijnego Lelewela, odzwierciedla język środowiska szlachecko-inteligenckiego pierwszej połowy XIX wieku, w którym istotną rolę odgrywały związki pokrewieństwa i powinowactwa rodzinnego, o czym świadczy bogato potwierdzone w listach słownictwo z tego kręgu tematycznego ${ }^{7}$. Wśród ekscerptów wskazać można określenia ogólne, odnoszące się do stosunków pokrewieństwa, jak

7 Nazwy stopni pokrewieństwa i powinowactwa rodzinnego mają relatywny i korelatywny charakter. Relatywizm łączy się z faktem, że nazwy określają daną osobę ze względu na jej stosunek do innej osoby spokrewnionej lub spowinowaconej. Natomiast korelatywność oznacza, że terminy zawierają w sobie stosunek dwustronny (Szymczak, 1966, s. 12). 
i szczegółowe nazwy stopni relacji osób połączonych więzami krwi. Pojęcia ogólne reprezentowane są przez następujące leksemy: dom '1. rodzina, domowi; 2. ród, familja' I 192 (dom rodzicielski I 170), familia I 161, generacja 'pokolenie, potomstwo' I 407, rodzina II 425; nazwy osobowe: domowy 'w jednym domu mieszkający' I 460, krewniaczka II 61, krewniak II 267, krewny I 298; nazwa abstrakcyjna: krewieństwo '1. związek po krwi, pokrewność; stosunek do siebie osób połączonych przez związki rodzinne; krewni; 2. osoby należące do jednéj rodziny po ojcu i matce' I 195, a ponadto wyrażenie po kadzieli '(w wyliczaniu stopniów pokrewieństwa) linja żeńska’: [...] rozwoju tej rodziny po kądzieli, sięgając wyżej kasztelanowej Chrapowickiej, jej brata i sióstr II 374.

Nomenklatura szczegółowa odnosi się do nazw stopni pokrewieństwa. Są to nazwy stopni pokrewieństwa w linii prostej i bocznej. Określenia stopni pokrewieństwa w linii prostej obejmują: a) stopień pierwszy, na który składają się nazwy odnoszące się do dzieci: córka I 19, dziecko II 210, potomek I 420, syn I 472; oraz nazwy wskazujące na rodziców: matka I s. XVII, ojciec I s. XVII; rzeczowniki zbiorowe: dziatwa II 50, potomstwo II 73, rodzice I 31; b) stopień drugi: babka II 60, dziad I 146, dziadek I 481, wnuczka II 457, wnuk I 462; c) stopień trzeci (i dalszy): prababka II 428, pra-pra-wnuk II 477, praszczur' 1 . syn prawnuka; 2. ojciec prapradziada. Praszczury, w ogólności, przodkowie’ II 61, prawnuk I 220.

Nazwy stopni pokrewieństwa w linii bocznej odnoszą się do nazw stopni: a) drugiego: Brat I s. XVII, cioteczny 'p. od ciotki. Cioteczni bracia albo siostry, które się rodzą od dwóch siostr' II 452, siostra I s. XVII, siostra cioteczna II 84, zbiorowo: rodzeństwo I 342, w tym neosemantyzm braterstwo 'bracia', Co się $z$ braterstwem po powrocie $z$ Łucka dzieje? I 406; oraz b) trzeciego: ciocia II 227, kuzyn 'krewny, powinowaty' II 138, kuzynka I 420, przyrodni 'a) brat, siostra; $\mathrm{z}$ jednego ojca a nie $\mathrm{z}$ jednéj matki, lub z jednéj matki a nie $\mathrm{z}$ jednego ojca; b) = komu; pokrewny, powinowaty' II 138, stryj 'brat ojca, ojcowy' II 358, stryjeczny II 160, stryjeczny braciszek I 420, stryjenka II 452, synowiec 'syn brata, bratanek' I 407, wuj I 289, wujeczny 'od wujowstwa, krewny po matce. Wujeczny brat. Wujenna siostra' II 452.

Również nazwy stosunków powinowactwa rodzinnego stanowią w badanych listach rozbudowaną siatkę leksykalną. I w tym przypadku wskazać można określenia ogólne i szczegółowe. Do tych pierwszych należy nazwa osobowa:

8 Definicje podawane są za Słownikiem wileńskim (Zdanowicz, 1861).

9 W Słowniku wileńskim 1. 'bratni związek krwi'; 2. 'związek ścisły'; 3. 'braterska miłość'; 4. 'brat z żoną'. 
powinowaty I 105. Wśród leksyki szczegółowej odnoszącej się do relacji powinowactwa rodzinnego wymienić należy: a) nazwy powinowactwa między małżonkami: małżonek II 361, matżonka II 60, mąż I 457, połowica 'posp. żona' I 259, żona I s. XVII, żonaty I 428; b) nazwy powinowactwa rodzinnego w linii prostej: szwagier 'siostry mąż, żony brat' I 200, zięć I 426; c) nazwy powinowactwa rodzinnego w linii bocznej, obejmujące: stopień drugi, do którego należą leksemy: bratowa I 391, macocha I 426, pasierb I 132, pasierbica I 426, oraz stopień trzeci, który reprezentowany jest przez rzeczownik: siostrzeniec II 452.

Z instytucją matżeństwa I 192 łączą się natomiast inne określenia, niemieszczące się w wyżej przedstawionych polach wyrazowych, które związane są także ze stanem poprzedzającym akt zawarcia związku małżeńskiego. Można wśród nich wyróżnić następujące ekscerpty: a) nazwy osobowe wskazujące na płeć i stan cywilny: dzieweczka 'białogłowa młoda niezamężna' I 438, kawaler '1. ten co sie stara o rękę panny, aspirant; 2 . mężczyzna nie żonaty, pozostający w bezżeństwie' I 265, narzeczona II 77, oblubienica 'narzeczona; obiecana, przyszła małżonka' II 103, pan młody II 365, panna I 391, panna młoda II 365, oraz związane z przygotowaniem do ślubu: swat II 308, swatka II 441; b) nazwy czynności i aktów uroczystych połączonych z przygotowaniem ślubu i wesela: poślubiny '1. zrękowiny, zaręczyny; 2. = zawarcie związku małżeńskiego, ślub’ II 200, przenosiny 'przeniesienie się po weselu panny młodej do pana młodego i biesiada $\mathrm{z}$ tej okoliczności' I 252, ślub II 77, ślubowiny II 443, świadkowanie II 457, wesele I 210, za mąż wydać I 457, zapowiedzie I 202, żenić się I 430, w tym osobnicze: zmatżonkować, [...] żyda zmałżonkowanego powtóre z katoliczką II 458.

Niemniej istotne w przestrzeni społecznej ówczesnej rodziny były także określenia związane z duchowym rodzicielstwem. W analizowanej korespondencji reprezentują je: a) nazwy osobowe: chrzestna I 457, chrzestna córka II 341, ojciec chrzestny II 52; b) nazwy czynności: prosić w kumy 'kum: ojciec chrzestny, kmotr' II 225, w tym idiolektalne: skumosić się: [Kleczyński - V. J.] [...] Jundziłła prosił w kumy, ale podobno że się z nim nie skumosi II 225.

\subsection{Językowe formy wskazujące na wewnętrzne zhierarchizowanie wspólnoty rodzinnej}

W analizowanej prozie epistolarnej Lelewela wyraźnie uwidacznia się tradycyjne wewnętrzne zhierarchizowanie rodziny - jej członkowie pozostają $\mathrm{w}$ rozmaitych stosunkach opartych na zasadzie równorzędności lub podrzędności i nadrzędności. To samo dotyczy krewnych i powinowatych. 
Układ hierarchii rodzinnej wynika $\mathrm{z}$ umiejscowienia w przestrzeni rodzinnej każdego z jej członków (Handke, 1995, s. 174). Przedstawione poniżej wybrane ekscerpty odzwierciedlają właściwe dla polszczyzny pierwszej połowy XIX w. zróżnicowane relacje personalne w obrębie patriarchalnego modelu rodziny, co na płaszczyźnie językowej sygnalizują przede wszystkim nazwy żon, synów i córek - formy posesywne tworzone od antroponimów, nazw zawodów, funkcji społecznych czy godności mężów i ojców.

Precyzyjne dookreślanie koneksji rodzinnych umożliwiały marytonimika przybierające formę opisową typu [...] Stefania Cieciszowska jest Sienkiewicza matżonka [...] II 377, Stara Subrowa matżonka wieśniaka z pod Częstochowy [...] II 421, częściej formacji na -owa, -ina oraz utworzonych przez zmianę paradygmatu męskiego na żeński od podstaw proprialnych: a) odimienne, np. Pani Józefowa I 134, pani Janowej I 166, pani Ignacowa II 172; b) odnazwiskowe, np. Aleksandrowska I 149, Pani Anna Bystrzyna I 476, Chońska I 149, Cyrinowa II 119, Dekertowa I 246, Glinczynie II 112, Mickiewiczowa II 119, JMCi Pani Morozowej I s. XVIII, Piczmanowa I 149, pani Piotrowska I 462, Mirowska I 149; c) odimienne i odnazwiskowe: Janowej Potockiej I 435, Jurkowska Wojciechowa I 149, pani Ludwikowej Wołowskiej II 185, pani Marcinowa Zalewska I 381, Wactawowa Luszczewska II 278; od podstaw apelatywnych, np. Pani marszatkowa I 426, p. ministrowa I 122, panie profesorowe I 156; oraz typ mieszany, składający się z nomen appellativum i nomen proprium, np. Bergmanowa zegarmistrzowa I 249, ciotuli Brzechwiny II 173, Jenerałowej Twardowskiej I 114, kasztelanowej Chrapowickiej II 374, księżna Marcinowa I 472, marszałkowa Nowowiejska I 427, pani Potocka Feliksowa z Rosia I 393, pani sąsiadka Szpicnaglowa I 203, ze Starościną Czacka I 272, Szczepańska kapitanowa II 119, Xiężna Dymitrowa Czetwertyńska I 393, Xiężna Radziwiłlowa I 237.

W przypadku mężatek Lelewel skrupulatnie zaznaczał ich powtórne zamążpójście, co językowo przybierało dwojaką realizację: We środę była na obiedzie hrab. Platerowa secundo voto (primo voto Lubomirska) I 426; Pani Muhlerowa, dziś Liśkiewiczowa I 23.

Wśród leksyki wskazującej na relacje ojciec - dziecko znajdują się określenia powstałe $\mathrm{w}$ wyniku operacji derywacyjnych i składniowych. Te pierwsze reprezentują patronimika męskie na -ic // -(ow)icz, -ak, np. dwaj generatowicze Żymirscy II 175, kasztelanic Czarnecki I 460, Netrebszczak II 172, pan sędzia prezydentowicz Michał Baliński I 265, pan wojewodzic Wodzicki $z$ Krakowa II 202; oraz patronimika żeńskie z przyrostkami -anka, -ówna, 
np. Adamowianki II 423, Gerszdorfówny I 110, Grodkówna I 204, Pinardzianka II 84, panien pocztmistrzówien II 409, wachmistrzniankę II 193, starościanka I 473. Patronimika derywowane składniowo obejmują przede wszystkim struktury męskie typu: syn + imię // nazwisko // nazwa zawodu, funkcji społecznej czy godności ojca w dop.lp., np. Jest dwóch Małachowskich, synów Henryka II 388; Ślubowskiego Józefa, syna Antoniego II 463; Był na tym popisie syn Czackiego I s. XXX; kuzynka [...] Suchodolskiego syna Januarego II 463; Godebski exkapitan, syn pótkownika II 457; młody // mały + nazwisko ojca w mian. lp., np. Młody Popławski syn Lustratora I 134, Wężyk młody II 119; małego Jaraczewskiego II 175; nazwisko ojca w dop. lp. + imię syna, np. Tatarów Jurek II 192; oraz odnazwiskowe deskrypcje żeńskie z rzeczownikiem córka + imię // nazwisko // nazwa zawodu, funkcji społecznej czy godności ojca w dop. lp., np. To synowie Cesi - Córki Józefa? II 387; Druga Gendebinowa Aleksandrowa [...] córka Barthelemy [...] II 422; córka bankiera Hanequin II 422.

Przy nazwiskach żeńskich funkcję patronimiczną pełnił także rzeczownik panna ${ }^{10}$ 'dziewczyna oświeceńszego stanu, lepiéj ukształcona', na co wskazuje poniższy przykład: [...] wdowa Dębińska, Dębińska panna i syn najstarszy nieboszczyka I 472. W przypadku nazwisk kobiet zamężnych relacje ojciec córka sygnalizowane są za pomocą konstrukcji z wyrażeniem z domu, np. Jest tu Eleonora Heltmanowa, Litwinka, z domu Dmóchowska II 377; [...] ona z domu Kossakowska II 387; Ona $z$ domu Puchalanka II 387.

O powiązaniach rodzinnych informują niekiedy określenia matronimiczne, wskazujące na relacje matka - dziecko, ale w badanej korespondencji Lelewela brak matronimików, choć pojawiają się wskazania na koligacje ze strony matki, np. Sa tu w Wilnie dwie osoby, co kalkulowaty, że pani bratowa, panna Slaska, musi się rodzić z Dębowskiej, czy to prawda? I 392.

Repertuar zjawisk językowych dotyczących „przestrzeni familijnej” (Handke, 1995, s. 51) obejmuje także nazwy par małżeńskich. Są to derywaty z sufiksami -owie lub -stwo utworzone od podstaw proprialnych: a) odimienne, np. Maciejowstwo II 191, Państwo Adamostwo I 161, Adolfostwo II 363, Julianostwo II 175, Protowie I 460, Ignacostwo II 175, Wacławostwo II 353; b) odnazwiskowe, np. Państwo Deszertowie I 129; c) odimienne i odnazwiskowe, np. Nosarzewscy Józefostwo II 175; d) odimienne i odnazwiskowe

${ }^{10}$ W polskich gwarach odpowiadają mu określenia dziewka, dzie(w)ucha (Zaręba, 1967, s. 236). 
+ adres odtoponimiczny, np. Pońscy Bolesławowstwo z Poznania II 387; e) odetniczne i odnazwiskowe, np. Podolanie Kotowiczostwo II 477; apelatywnych, np. PP. jeneralstwo II 267, sędziostwu I 213; apelatywnych i proprialnych, np. państwo Dobrowolscy I 436, PP. Majewskich I 202, Państwo Szefostwo Jackowie I 179, marszałkostwa Drzewieckich i referendarstwa Skibickich I 426. Nazwy małżeństw są stosowane konsekwentnie i wyodrębniane $\mathrm{z}$ nazw rodzin, co ilustruje poniższych przykład: Słowem zjawiła się na chwile pustka, bo wzajemne wizyty Guzowskich, Raczyńskich, Biernackich, Bertierów, Daszkiewiczostwa, Dębińskich, etc. sa rzadkie i z tych ubywa po trosze II 465.

W języku familijnym Lelewela w zakresie systemu nazw członków kręgu rodzinnego obecne są także określenia analityczne typu: W Paryżu znalazłem kuzynka naszej bratowej Maurycego Wrońskiego [...] II 82; kanonik Znamirowski, pana sędziego warszawskiego synowiec I 407; [...] Michałowska, kuzynka nasza z domu Oborska, Żabickiego cioteczna etc. II 113.

\section{Formy bezpośredniego osobistego kontaktu w rodzinie}

Komunikacja interpersonalna w każdej rodzinie dokonuje się na szerszym tle interakcji pomiędzy jej członkami. Intensywność wzajemnego oddziaływania uwarunkowana jest częstotliwością, trwałością i swoistością kontaktów (Harwas-Napierała, 2006, ss. 221-222). Ważnym narzędziem identyfikacji więzi społecznej w komunikacji wewnątrzrodzinnej są językowe formy zwracania się do siebie członków tej wspólnoty. Adresatywy ${ }^{11}$ obok funkcji fatycznej (nawiązania serdecznego kontaktu, okazania szacunku) i deiktycznej pełnią także funkcję relacyjną jako wykładniki określonego typu spoufalenia interlokutorów.

11 Synonimicznie: zwroty adresatywne // formy (formuły) adresatywne // formy adresu // sposoby zwracania się do drugich // tytulatura // formy honoryfikatywne to „wszystkie wypowiedzi performatywne, które za pomocą wyrażeń pronominalnych (np. pol. TY, WY) [...]), nominalnych (np. imię, nazwisko, tytulatura) i atrybutywnych (np. pol. MÓJ, SZANOWNY [...]) oraz ich potencjalnych kombinacji wytwarzają określony, społecznie wykształcony stopień i charakter dystansu między nadawcą a odbiorcą w bezpośrednim akcie komunikacji językowej" (Tomiczek, 1983, s. 25). 
Bliższa analiza badanych listów pozwala wyodrębnić w nich dwa typy wewnątrzrodzinnej komunikacji interpersonalnej, uzależnionej od relacji: nierównorzędnej, pionowej (dzieci - rodzice) i równorzędnej, poziomej (rodzeństwo). W korespondencji skierowanej do rodziców i babki językowym wykładnikiem pragmatycznej niesymetryczności relacji rodzinnej są trzecioosobowe formy czasowników, np. Jeśliby ojciec byt łaskaw i pod kopertą księdza biskupa do mnie chcial pisać [...] I 135; Matka zapowiedziała mi, że już ostatni list pisze [...] I 467. Do rodzeństwa natomiast Lelewel zwracał się zwykle przy użyciu form na ty, np. Pisałeś bracie, że [...] I 59; Zmartwito tė̇ mię zdrożne popstrykanie się Prota z Janem, o co? nieraczyłaś mi powiedzieć II 472. Relacja na ty mogła niekiedy przybierać formy liczby mnogiej. W takich przypadkach formy pluralne pełniły funkcję emotywną, zwiększając dystans pomiędzy komunikantami dyskursu familijnego, np. Jeźli macie [do brata Jana - V. J.] co pisać to piszcie, a jeźli niemacie nic, to bądźcie w oddaleniu z takiem sercem z jakim jest Twój brat Joachim II 32.

\subsection{Wyrażenia pronominalne}

Analiza wyekscerpowanych formuł adresatywnych ujawniła rozbudowaną sieć wyrażeń pronominalnych, wyznaczających społeczną przestrzeń rodziny (Handke, 1995, s. 89). W komunikacji wewnątrzrodzinnej istotną jest postawa egocentryczna, związana z centralnym usytuowaniem mówiącego względem innych krewnych i powinowatych, którą wyznacza zaimek osobowy ja, przeciwstawiający się pozostałym zaimkom osobowym. Językowymi śladami relacji łączących nadawcze ja z pozostałymi uczestnikami dyskursu rodzinnego są zaimki osobowe ty i $w y$, współtworzące atmosferę bezpośredniości i familiarności, np. Takiego życia jakiego ty dziś używasz, już ja zapróbowat w tej Francyi. Z przypadku żyłem na cudzym chlebie II 37; Ja $z$ Michałem poszliśmy ogladać składy [...] I 481; Co do mnie wszystko idzie dobrze I 105; Zgon brata Jana jest dotkliwym dla mnie ciosem II 324; Musze ci jeszcze donieść [...] I 60; Mam do ciebie prośbę, z której pewnie się będziesz śmiał, ale zrobisz mi łaskę, o to, żebyś pisał listy do mnie po bratersku i po przyjacielsku [...] I s. XVII; [...] dopiero dziś zdążam wieczorem pisać list do was, bracia [...] I s. XIII; Tymczasem tulę Was do serca II 359. Egocentryzm ujmowany z perspektywy odległości fizycznej pomiędzy członkami rodziny może przyjmować następującą werbalizację: Niebyło u was zimy, u nas była jaka taka, słotna, dość pogodna, z lekkiemi przymrozkami II 295; U nas tu 
wszyscy zdrowi, wyjąwszy u państwa Adamów katar przy teraźniejszej wilgoci opanowat [...] I 129.

Zaimki dzierżawcze wyznaczają natomiast granice przestrzeni osobistej każdego z członków wspólnoty rodzinnej, przy czym zaimek mój wytycza granicę przestrzeni życiowej podmiotu mówiącego, np. [...] cenzura zechce kieszeń moja na nowy expens narazić I 129; [...] co rada familijna zadecyduje, na to $z$ mej strony przystaje I 312; przeciwstawiając ją innym krewnym, np. Panna Marcella o braciach swoich zapomniała [...] I 161; List Twój z daty 8 Maja odebratem II 30; Nad twoja choroba boleję niezmiernie [...] II 106; Polecam sie rodzinnej pamięci Waszej II 363. Zaimki dzierżawcze mogą wskazywać także na mikroprzestrzeń rodzinną, np. Uściskaj odemnie siostry i dzieci Wasze II 384, lub odnosić się do całej rodziny, np. Pisałem do domu, żeby z naszej Woli tu do Łucka się przywlekli, miałby przynajmniej nasz dziadunio rozrywkę [...] I 160; Państwo Adamostwo chore i w smutkach. Smutne w samej rzeczy wypadki nasza familia trapia [...] I 161; Będzie on [Górecki - V. J.] wkrótce przez Warszawe przejeżdżał, spodziewam się, że nasz dom nawiedzi I 196; Pani Józefowa Marcelce wspominała o bliskiem z niemi sąsiedztwie, zapewne nasz zakątek odwiedzą I 134; Piszesz o biedzie w naszych stronach [...] I 52. Zaimek nasz nie tylko służy zatem przeciwstawieniu środowiska familijnego reszcie świata, lecz także pełni dodatkowo funkcję integrującą członków kręgu rodzinnego (Handke, 2008, s. 110).

\subsection{Wyrażenia nominalne $i$ atrybutywne}

Elementem konstytutywnym zwrotów adresatywnych w analizowanych listach jest tytulatura familiarna ${ }^{12}$, prawie obligatoryjnie, zgodnie z ówczesnymi zwyczajami (Budrewicz, 2000, s. 203), w stosunku do rodziców i starszych krewnych z formułą Dobrodziej // Dobrodziejka // Dobrodziejstwo. Co ciekawe, analizowane adresatywy w kontaktach $\mathrm{z}$ rodzeństwem nie przybierają form odimiennych, z których chętnie korzystał w swych listach np. Sienkiewicz (Mariak, 2016, s. 21), brak im też oryginalności. Intensyfikowaniu nacechowania emocjonalnego form adresatywnych służyły konstrukcje deminutywne tworzone od nazw pokrewieństwa oraz przymiotnikowe i imiesłowowe ekspresywa.

12 E. Tomiczek zalicza do niej „te wszystkie formy nominalne, które oznaczają stopnie pokrewieństwa albo powinowactwa i mogą być użyte w funkcji adresatywnej wobec osób spokrewnionych i spowinowaconych w obrębie najmniejszej grupy społecznej, jaką stanowi rodzina" (Tomiczek, 1983, s. 181). 
Są to epitety atrybutywne typu: łaskawy, kochany // ukochany, pojawiające się najczęściej w stopniu najwyższym. Tym samym formuły te można interpretować jako próbę pogodzenia konwencji i szczerego uczucia nadawcy. A oto przykładowe ekscerpty form zwracania się Lelewela w listach do:

- ojca, np. WP Dobrod. I 17, WMP. Dobr. I 41, W. Pan Dobrod. I 17, W. Pan Dobrodziej I 2, Tatunio Dobr. I 17, Najukochańszy Ojcze Dobrodzieju! I 89, Najukochańszy Ojcze! I 140, Mon trés cher Pére! I 53, Ojciec Dobr. I 48, mój Ojcze I 75;

- matki, np. Matka Dobrodziejka I 342, Najukochańsza Matko Dobrodziejko! I 351, Najukochańsza Matko! I 405;

- rodziców, np. Najukochańsi Rodzice Dobrodziejstwo! I 105, Najukochańsi rodzice! I 162;

- braci Jana i Prota, np. Panie Bracie II 85, pan Prot I 135, Bracie! I s. XIII; Bracie kochany! I s. XXVII, Bracie łaskawy! I 18, Kochany Bracie! I 30, Najukochańszy Bracie! I s. XVIII, Braciszku! II 79, Najukochańszy Braciszku! I s. XII, Kochana rodzino! [do brata Prota] II 344, braciszku II 91;

- siostry Marii, np. Kochana Siostro! II 407, Do kochanej siostry w Szydłowie II 467, Kochana, najukochańsza siostro! II 478, siostro II 411.

Formy adresatywne występują w różnych pozycjach struktury listów. Obligatoryjnie wchodzą w skład wpisujących się w etykietalną konwencję epoki formuł grzecznościowych lokowanych w ramowych partiach listów, które pragmatycznie składają się na makroakty powitania lub pożegnania.

\section{Emocjonalność w komunikacji wewnątrzrodzinnej}

Znamienną cechą kodu familijnego jako podsystemu języka potocznego (Handke, 2008, s. 76) jest jego nacechowanie emocjonalne. W analizowanych listach manifestacja uczuć przybiera często postać formuł eksplicytnych, w których nadawca explicite informuje odbiorcę o swoim stanie emocjonalnym, np. Zmartwiło też mię zdrożne popstrykanie się Prota $z$ Janem [...] II 472; Z tęsknota Was czule ściskam [...] II 283; Tęskny uścisk II 306; Kochana siostro! Troszczę się o Was i nie wiem za co od niejakiego czasu dużo niespokojny jestem II 407; Żal bierze jak pod pięknym płaszczykiem sama młodzież daje się jezuityzmem uwodzić i upadlać II 46; U nas towarzystwo rozpoczęło swe posiedzenia, przykro mi było, żem nie miał czego na samym wstępie złożyć i czytać I 92. 
Uczucia nadawcy uzewnętrzniane są także za pomocą różnorodnych środków językowych: leksykalnych i składniowych.

\subsection{Leksykalne sposoby wyrażania emocji}

Wśród wyekscerpowanych emocjonalizmów leksykalnych wyrazistą grupę stanowią nieoficjalne formy osobowych nazw własnych. Znamiona intymności rodzinnej mają przede wszystkim zdrobniałe i spieszczone formy imion rodzeństwa, np. Jasio I 21, Józieńkowi I s. XIII, Józiowi i Marcelce I s. XIV, do Mani II 225, z Marcelka I 73, Maryli I s. XXXIV, Marynia I 469, Marysia II 56, Protkowi I s. XIII; bratanków i siostrzeńców, np. [dzieci Prota] Ewci II 343, Helenka II 351, z Hugonkiem II 84, oba chłopczyki Huguś z Gucikiem II 100, Juliś I 176, mały Henryczek I 110; oraz dalszych krewnych i powinowatych, np. Adaś i Michaś I 129, ciocia Antolka [Antonina Netrebska, z domu Cieciszowska] II 174, Antoś I 420, Brunek [Brunon Kiciński, brat cioteczny] I 197, Cesi Cieszkowskiej II 473, Emilka I 447, Janka Majewskiego [szwagier, mąż Marii] II 416, Józi [żona Prota] II 198, Kazio Cieciszowski [brat cioteczny] II 31, Krysi [Krystyna z Kicińskich Potocka] II 95, Klemenci Hoffmanowej II 177, na ręce Klemuni [Klementyna z Tańskich Hoffmanowa] II 33, wujaszek Pawetek Cieciszowski z Guciem swym II 424, Paulinkę [z domu Dmóchowska, żona Augusta Lelewela] II 394, o Stasiu Deszercie I 221; wreszcie dzieci dalszych krewnych i znajomych: przyjazd Kluczewskiej z Kacperkiem i Zosia I 481. Niektóre $\mathrm{z}$ nacechowanych antroponimów pomimo obecności formantu augmentatywnego wykazują zabarwienie melioratywne, na co jednoznacznie wskazuje uwarunkowanie pragmatyczne, np. Prot z żona i kilku dziatwy, zapewne $z$ Hugoniskiem $w$ Busku; musi być z Hugonkiem nie najlepiej jest to siódmy roczek jemu II 84.

W języku familijnym Lelewela pewną oryginalnością charakteryzują się nieoficjalne formy nazwisk i przezwiska, które wprowadzał do epistolarnej komunikacji rodzinnej ze względów emocjonalno-humorystycznych: [...] frasuję się bez końca nad Lokietkiem [Hugon, syna Prota; ze względu na jego niski wzrost], co za nieszczęśliwa istota! II 108; Samemu także panu „z Finków” Piaskowskiemu złóż ukłony [...] I 182; Krótko piszę, przez Fijałka [Fijałkowski, brat arcybiskupa warszawskiego] II 279. W listach do najbliższych pisanych na emigracji pojawiają się także kryptonimy (Jaros, 2017): Dzięki nieskończone za obszerny list przez mydlarza [Cyprian Zabłocki] II 279; Żaba od was powróciła II 117; Pisze przez Żabkę [Tadeusz Żabicki, siostrzeniec Joachima] II 59; 
Z ostatnich słów wyrozumiewam, że pani Szydłowska [siostra, Maria Majewska, zamieszkała w Szydłowie] myśli tylko szwajcarskie śniegi oglądać [...] II 290; Moja pani Krakowska [Elżbieta z Nowowiejskich Mickiewiczowa; po poddaniu się Warszawy osiadła w Krakowie; przyjaźniła się z siostrą Joachima] II 60; pan $z$ Nakwasina [Henryk Nakwaski] II 66; Baba [kryptonim Lelewela] niechce, żeby wielkie pany na niq kwesty robili [...] II 270; Musisz wiedzieć adres do Neidenburga czyli Niborka [...] II 38; w tym odantroponimiczne i odtoponimiczne akronimy, np. Siostra An. Ne [Antonina Netrebska] II 189; Coś pisał o A. [Adam Łuszczewski] braciszku Kostuli [Konstancja Łuszczewska, krewna Lelewela z linii Cieciszowskich] II 35; do Woli C. [Cygowskiej] II 181; jedynie M. M. [Maria Majewska, siostra] zamierza II 181; doszedt mnie list pisany ręką $\boldsymbol{P}$. [Prota] II 34.

Do repertuaru familijnego należą także emocjonalizmy odapelatywne. "Język miłości i czułości” (Handke, 2008, s. 131) w analizowanych listach współtworzą deminutywne i hipokorystyczne formy nazw pokrewieństwa i powinowactwa, np. matka - mama I 125, mamula II 175, Mamuleńka I s. XXXIV, Mamuni I s. XI, Matuli I s. XIII; ojciec - Tatula I s. XIII, Tatuleńko I s. XXXII, Tatunio I 54, Tatusia I s. XI; babka - babula II 42, babulka II 439, Babuleńka I s. XIX; brat - braciszek I 420; siostra - siostrzyczkę II 419; syn synkowi I 109; córka - z córeczka II 371; panna - panienka I 199; dziadek - dziadunio I 160, Dziaduszkę I 447; ciotka - cioci II 227, ciotuli II 173, Ciotunia I 166; wuj - wujaszka II 355; żona - żonka I 133; kuzyn - kuzynek II 35; a także inne wyrazy zdrobniałe, np. Spodziewam się bowiem raniuteńko dziś w podróż wyruszyć byle furman zajechał I 400. Dziś idę na śniadanko polskie do Adama Pauszy [...] II 137; [...] konsolowałem go jak mogłem buteleczka I 213; Czytam o trzech kochanych chłopczykach [...] II 342. Szczególną kondensację emocjonalizmów odapelatywnych obserwujemy w formułach etykietalnych, np. Pocałuj raczki Babuni, Mamuni i Tatunia Dobrodziejów [...] I s. XI; Pokłoń się Siostrzyczkom i Braciszkom odemnie, Józieńkowi oddaj kogutka I s. XIII; Wszystkim starszym rączki i nóżki całuję, młodszych serdecznie ściskam I 195.

Osobną grupę stanowią leksemy, w których emocjonalność jest jednym ze składników semantycznych znaczenia wyrazu, zawartych systemowo w strukturze definicyjnej leksemu lub konotowanych, np. [...] odmłodniewa długo zgrzybialy uniwersytet I 357; [...] sędzia sprawił się jak nie sędzia, ale jak wartogłów. Burmistrz, dobra duda [...] II 45; [...] bo go [list - V. J.] totr Bobrowicz przetrzymat, zrywam z tym paskudziarzem [...] II 202. 
W budowaniu wypowiedzi nacechowanych emocjonalnie w listach Lelewela niemały udział mają również figury retoryczne, a zwłaszcza potoczne metafory, np. [...] prace i trudy ugrzęzną $w$ błocie Krzemienieckiem, nigdy nie wysychajacem I 185; Wyobrażam sobie, jak wszystko tam podrosło, zbabiało, zdziadziało [...] II 312; [...] pewnie emigracya $w$ ciuciubabkę grać nie zaniedba II 92; porównania, np. Żadanie podobne jest jakby kowalowi kazał kuć, zabrawszy mu młot i kowadło II 71; frazeologizmy, np. Co bądź siedzę jak szczur na ołtarzu, któremu kadza [...] I 352; Nieład jak groch z kapusta, tu trocha, owdzie trocha [...] I 332; [...] w Wilnie siedze jak za piecem [...] I 199; Siedź grzybie, dopóki Cię kto niezdybie II 290; Co ma wisieć, to nieutonie I 415; [...] niechciałem grochu rzucać na ścianę I 160.

\subsection{Emocjonalność związana z organizacją wypowiedzi}

Do emocjonalizmów składniowych w badanej korespondencji należą właściwe mowie potocznej wypowiedzenia wykrzyknieniowe, co ilustrują ekscerpty: Teraz żyję sobie swobodnie, wygladam jednak końca roku i kandydactwa, będę tedy w domu! będę się cieszyt, skakat, radowat ...! I 118; Oby mi się zbliżł moment przeniesienia się do Warszawy! I 325; U nas teraz bieda! I 131; wykrzyknienia parajęzykowe, np. Ale, ale! Z nowin, o czem może niewiesz, Bruno Kiciński przeniósł się do wieczności II 200; Tam to hm! hm! Ale nie do mnie [...] I 206; Zagraniczny pfe, do cudzoziemczego pisma peryodycznego po polsku nic pisać nie moge, strojów pięknych Jagiellońskich zcudzoziemczyć nie chcę I 291; Dla honoru królestwa i władz sadowych wypadałoby coś odpisać, $\dot{z} e$ się to tak wlecze, to az pfe I 413; oraz partykuły emocjonalne, np. Oh, jak to tym ludziom lekko nami poniewierać! II 300; Ależ i mój druk, oh! kiedyż się skończy? II 338; Dojdź że tu prawdy w filozofii! II 230.

Wyraźnymi sygnałami zaangażowania emocjonalnego Lelewela są także inwokatywy typu: Ale chwała Panu! Wszystko się tam na wesela, jak mi Prot pisze, zbiera I 206; [...] matka piękne projekta formuje. Daj Boże je doczekać I 263; Daj Boże żeby tak nie było! II 32; Szczęść im Boże! I 293; Dzięki niebu! zaczyna loterya nagradzać I 320; Niech was Bóg pociesza II 301.

Wartość emotywną wypowiedzi wzmacniają dodatkowo powtórzenia leksykalne, np. Oh! nic z tego, nic, nic być niemoże, chyba że się ludzkie spękaja rachuby II 449; Braciszku! po dtugiem, długiem, dtugiem bardzo milczeniu prawdziwie niewole się do pisania II 235; Najciężej co zacząć, jak się zacznie, jeśli przerwy niema to się maluczko, maluczko ukończy [...] II 369; w tym 
właściwe dziś jeszcze gwarom, a w przeszłości potwierdzone m.in. w idiolekcie Syrokomli (Trypućko, 1957, ss. 100-101) konstrukcje składniowe typu: [...] wszystkim a wszystkim najpowinniejsze składam atencye I 170; Życie w Belgium i Bruxelli jest tańsze niż we Francyi [...] Piwa bez końca, tego pija a pija Belgi dniem i noca, ztąd ociężali i odurzeni ztąd ich betise II 50.

Do budowania emocjonalnego napięcia wykorzystywał Lelewel także znane mowie potocznej przerywniki i zdania urwane, np. Na górze stoją kupkami kolumny po cztery, między niemi sa pułki i książki..., ale... przerywam dalsze pismo, bom sobie bardzo ważną rzecz przypomniał I 16; Byłaby prawda karyera wówczas już stała, ale, ale... i bardzo ale... I 263; Ojciec Dobrodziej pyta mnie, czy wznawiać o bibliotekarstwo kwestje? Niewiem sam co na to mam... I 294.

Innym zabiegiem wzmacniającym emocjonalność wypowiedzi było wprowadzanie replik narratora i jego rozmówców, np. Lubliner autoruje ciagle i często styszę, uf! co ja za pracę mam, uf! II 467; [...] tylkom się nie wyspat, bo Onaczewicz ni spać ni drzymać mi niedat, caly dzień gadat, rozpowiadał potwierdzał tak, tak, i szukał zwady, a w nocy wzdychał oh! oh! oh! bo go pchty gryzły, a ze świtem, ba i o północy furmana huczał, budził, łajał, straszył, groził I 420; Lecz ze świtem w poniedziałek, zaledwie mój Ostatnigrosz [tak Lelewel przezwał Żyda woźnicę - V. J.] brykę nasmarowat, uderzył w lament, a je je je! a je je je! ledwiem się dopytat, że gleit i cettel zgubił I 438; [...] woźnica mój spał, tylko przez sen powolywat na konie mocno i syllabami, nu, nu, wiu, wio, oo, a odcykając się niekiedy gwizdną fit I 338.

\section{Podsumowanie}

Przedstawiona w niniejszym szkicu analiza języka familijnego Joachima Lelewela ma wprawdzie charakter wybiórczy, pozwala jednak wskazać kilka zjawisk językowych dotyczących relacji między członkami najbliższej rodziny, w tym właściwości niebadanej dotychczas osobistej sfery idiolektu historyka. Można je ująć następująco:

- Badany język familijny odzwierciedla właściwe dla dziewiętnastowiecznej polszczyzny zhierarchizowanie struktury przestrzeni społecznej rodziny nazwy rodzinne, na które składają się nazwy pokrewieństwa i powinowactwa, oraz analityczne i deskrypcyjne marytonimika i patronimika, określenia par małżeńskich tworzą bogaty repertuar leksykalno-semantyczny, służący precyzyjnej identyfikacji poszczególnych członków rodziny. 
- Interpersonalna komunikacja wewnątrzrodzinna uzależniona jest od typu relacji łączącej członków rodziny. Na partnerskie stosunki w obrębie rodziny eksplicytnie wskazują użycia 2. os. l. poj. orzeczenia, wykładnikiem pragmatycznej niesymetryczności relacji rodzinnej są trzecioosobowe formy czasowników.

- Na określenia wyznaczające typ więzi między członkami rodziny składają się: a) przymiotniki drogi, kochany // ukochany, łaskawy (nierzadko w superlatywie); b) formy deminutywne i hipokorystyczne określeń pokrewieństwa, np. Tatunio, Babunia, Mamunia, Tatuleńko, Braciszku, Siostrzyczki, ciotunia, wujaszek; c) nieoficjalne imiona (ale nie w funkcji zwrotów do adresata), np. Huguś, Klemunia, Mania, Marysia, Protek.

- W sposobach zwracania się do bliskich obecne są liczne wyrażenia pronominalne, nacechowana melioratywnie tytulatura familijna, $\mathrm{z}$ którą łączą się określenia atrybutywne, w formułach salutacyjnych i adresatywach natomiast zupełnie brak imion, choć takowe występują w tych pozycjach już od pocz. XVII w. (Mroczek, 1978, s. 139).

- Zwroty honoryfikatywne - oprócz podstawowej funkcji adresu - podporządkowane są strategiom komunikacyjnym służącym konstruowaniu pozytywnego wizerunku odbiorcy i/lub budowaniu serdecznej, familiarnej atmosfery interakcji pomiędzy interlokutorami z zachowaniem należytego każdemu z członków rodziny uszanowania, podtrzymywaniem uczuciowej więzi pomimo fizycznej rozłąki.

- Formy adresatywne uzewnętrzniają uczucia miłości, wdzięczności i szacunku dla starszych członków rodziny, zwłaszcza rodziców i babki, z niepodważalną pozycją ojca jako głowy rodu. Familiarne adresatywy kierowane do najstarszych członków rodziny zawierają elementy ówczesnego rytuału etykietalnego - formuły Pan // Pani, Dobrodziej // Dobrodziejka // Dobrodziejstwo, które konwencjonalizują się, mogą bowiem być skracane, np. P. Szelutta, Dobrod. // Dobr., JWPan.

- Realizacja języka familijnego sytuuje się w obrębie języka potocznego neutralnego i nacechowanego. Wykładnikami rejestru emocjonalnego jest ekspresywna leksyka (m.in. deminutywa i hipokorystyka apelatywne, nieoficjalne formy antroponimów, potoczna metaforyka, porównania i frazeologia) oraz środki składniowe (eksklamacje, inwokatywy, przerywniki i zdania urwane, powtórzenia, wprowadzanie replik narratora i jego rozmówców). 
- O zindywidualizowaniu języka rodzinnego Lelewela świadczą nieliczne neologizmy: zmatżonkować, skumosić i neosemantyzm braterstwo, żartobliwe przezwiska i nieoficjalne formy antroponimów, a także zachowania językowe związane $\mathrm{z}$ utajnieniem wskazań referencjalnych - w języku familijnym historyka $z$ okresu jego pobytu na emigracji pojawiają się elementy języka tajnego (kryptonimy, odantroponimiczne i odtoponimiczne akronimy), co podyktowane było troską o bezpieczeństwo własne i najbliższych.

\section{Bibliografia}

Bokszański, Z., Piotrowski, A., \& Ziółkowski, M. (1977). Socjologia języka. Warszawa: Wiedza Powszechna.

Budrewicz, T. (2000). Intytulacje i submisje w listach pisanych do Józefa Ignacego Kraszewskiego. W J. Sztacherska \& E. Dąbrowicz, Sztuka pisania: O liście polskim w wieku XIX (ss. 193-209). Białystok: Wydawnictwo Uniwersytetu w Białymstoku.

Gajda, S. (1988). Styl indywidualny a współczesna stylistyka. W J. Basara (Red.), Z polskich studiów slawistycznych (Seria 7, ss. 377-384). Warszawa: PWN.

Handke, K. (1995). Polski język familijny: Opis zjawiska. Warszawa: Slawistyczny Ośrodek Wydawniczy.

Handke, K. (2008). Język familijny. W K. Handke, Socjologia języka (ss. 75-133). Warszawa: Wydawnictwo Naukowe PWN SA.

Harwas-Napierała, B. (2006). Komunikacja w rodzinie ujmowanej jako system w relacji rodzice - dzieci. Roczniki Socjologii Rodziny, 17, 221-233. Pobrano 24 czerwca 2018, z https:// repozytorium.amu.edu.pl/bitstream/10593/4975/1/13_Barbara_Harwas_Napierala _Komunikacja_w_rodzinie_ujmowanej_jako_system_221-233.pdf

Jaros, V. (2009). Niektóre osobliwości leksykalne w języku Joachima Lelewela. W B. Milewska \& S. Rzedziecka (Red.), Wokół słów i znaczeń: 3. Z zagadnień leksykalno-semantycznych (ss. 391-400). Gdańsk: Wydawnictwo Uniwersytetu Gdańskiego.

Jaros, V. (2013). Fleksja rzeczownikowa w pismach naukowych Joachima Lelewela. W K. Kowal \& A. Konert (Red.), W poszukiwaniu fundamentów czyli o potrzebie stałości w zmieniającym sięświecie (ss. 507-524). Częstochowa: Wydawnictwo AJD im. Stanisława Podobińskiego.

Jaros, V. (2014). Osobliwe formy denominalnych derywatów czasownikowych w wybranych pismach naukowych Joachima Lelewela. W E. Rogowska-Cybulska \& E. Badyda (Red.), Wokół słów i znaczeń: 6. Słowotwórstwo dawne i współczesne (ss. 130-140). Gdańsk: Wydawnictwo Uniwersytetu Gdańskiego.

Jaros, V. (2015). Studia nad językiem i stylem pism naukowych Joachima Lelewela. Częstochowa: Wydawnictwo AJD im. Stanisława Podobińskiego. 
Jaros, V. (2017). Nazwy maskujące w emigracyjnych listach Joachima Lelewela pisanych do przyjaciół i znajomych. Język Polski, 2017(3), 76-86.

Kałkowska, A. (1982). Struktura składniowa listu. Wrocław: Zakład Narodowy im. Ossolińskich.

Kieniewicz, S. (1990). Joachim Lelewel. Warszawa: Książka i Wiedza.

Kozłowska, A. (2011). O stylistycznym zróżnicowaniu idiolektu (na przykładzie tekstów Karola Wojtyły - Jana Pawła II). W U. Sokólska (Red.), Odmiany stylowe polszczyzny dawniej i dziś (ss. 89-107). Białystok: Wydawnictwo Uniwersytetu w Białymstoku.

Lewaszkiewicz, T. (1976). Osobliwości leksykalne w języku Joachima Lelewela. Slavia Occidentalis, 33, 59-74.

Mariak, L. (2016). Właściwości leksykalne języka familijnego Henryka Sienkiewicza (na podstawie korespondencji prywatnej). W B. Taras \& W. Kochmańska, Język nasz ojczysty w sferze życia rodzinnego (ss. 15-29). Rzeszów: Wydawnictwo Uniwersytetu Rzeszowskiego.

Maternicki, J. (2009). Joachima Lelewela idea historii zaangażowanej. W J. Maternicki, Historia i życie narodu: Pogladdy i postawy historyków polskich XIX i XX wieku (ss. 56-84). Rzeszów: Wydawnictwo Uniwersytetu Rzeszowskiego.

Mroczek, K. (1978). Tytulatura w korespondencji staropolskiej jako problem stosunku między nadawcą a odbiorcą. Pamiętnik Literacki, 69(2), 127-148.

Szymczak, M. (1966). Nazwy stopni pokrewieństwa i powinowactwa rodzinnego $w$ historii i dialektach języka polskiego. Warszawa: Państwowe Wydawnictwo Naukowe.

Tomiczek, E. (1983). System adresatywny wspótczesnego języka polskiego i niemieckiego. Socjolingwistyczne studium konfrontatywne. Wrocław: Wydawnictwo Uniwersytetu Wrocławskiego.

Trypućko, J. (1957). Język Władysława Syrokomli (Ludwika Kondratowicza): Przyczynek do dziejów polskiego języka literackiego w XIX wieku (T. 2). Uppsala: A.-B. Lundequistska Bokhandeln.

Urbańczyk, S. (1983). Uwagi o polszczyźnie prac Joachima Lelewela. Język Polski, 63(3), 170-179.

Więckowska, H. (1980). Joachim Lelewel: uczony - polityk - człowiek. Warszawa: Czytelnik.

Zaręba, A. (1967). Formy nazwisk żon i dzieci w dialektach języka polskiego. Onomastica, 12, 232-275.

Zdanowicz, A (Red.). (1861). Słownik języka polskiego (T. 1-2). Wilno: Maurycy Orgelbrand.

\section{Źródła}

Lelewel, J. (1878). Listy Joachima Lelewela: Oddział pierwszy. Listy do rodzeństwa pisane (T. 1) [I]. Poznań: J. K. Żupański.

Lelewel, J. (1879). Listy Joachima Lelewela: Oddział pierwszy. Listy do rodzeństwa pisane (T. 2) [II]. Poznań: J. K. Żupański. 


\title{
A Description of Joachim Lelewel's Familial Language Concerning the Family Social Space (on the Basis of Letters to His Loved Ones)
}

\author{
Summary
}

This article is a contribution to research on Joachim Lelewel's familial language. The study is limited to a range of linguistic phenomena concerning the family social space, and considers the two-volume collection of his letters from many different places written in various periods of his life. The epistolary prose under examination reflects the language of nobility and intelligentsia circles of the first half of the nineteenth century, with its distinctly marked hierarchical structure of the family social space. Its exponents include family names (e.g. the names for kinship and family relations, maritonymics and patronymics, names used with reference to married couples), familial forms of address (with the conventional forms Pan/Pani 'Sir/Madam', Dobrodziej/Dobrodziejka/Dobrodziejstwo 'Sir/ Madam/Sir and Madam', lit. 'benefactor/benefactress/benefactors' in relation to the elderly), emotional colloquial vocabulary and unofficial anthroponyms. This use of familial language, characterised by infrequent use of personalised forms, belongs to marked informal register.

\section{Charakterystyka języka familijnego Joachima Lelewela dotyczącego społecznej przestrzeni rodziny (na podstawie listów do najbliższych)}

\section{Streszczenie}

Niniejszy szkic stanowi przyczynek do poznania właściwości języka familijnego Joachima Lelewela. Charakterystyka ograniczona została do repertuaru zjawisk językowych dotyczących społecznej przestrzeni rodziny. Podstawę materiałową tworzy dwutomowy zbiór korespondencji pisanej z wielu 
miejsc pobytu w różnych okresach życia historyka. Badana proza epistolarna odzwierciedla język środowiska szlachecko-inteligenckiego pierwszej połowy XIX wieku, w którym wyraźnie zaznacza się zhierarchizowanie struktury przestrzeni społecznej rodziny, czego wykładnikami są nazwy rodzinne (m.in. nazwy pokrewieństwa i powinowactwa, marytonimika i patronimika, określenia par małżeńskich), familiarne adresatywy z konwencjonalnymi formułami Pan // Pani, Dobrodziej // Dobrodziejka // Dobrodziejstwo w stosunku do starszych, emocjonalną leksyką potoczną i nieoficjalnymi antroponimami. Realizacja języka familijnego, w którym ujawniają się nieliczne indywidualizmy, sytuuje się w obrębie rejestru nacechowanego języka potocznego.

Keywords: familial language; idiolect; family names; forms of address; letter

Słowa kluczowe: ęzyk familijny; idiolekt; nazwy rodzinne; formy adresatywne; list

Violetta Jaros, Jan Długosz University in Częstochowa

ORCID: https://orcid.org/0000-0003-0479-2503

Correspondence: violetta.ajd@gmail.com

The preparation of this article was financed by the author.

Competing interests: The author declares that she has no competing interests. 